\title{
Modicisalibacter tunisiensis gen. nov., sp. nov., an aerobic, moderately halophilic bacterium isolated from an oilfield-water injection sample, and emended description of the family Halomonadaceae Franzmann et al. 1989 emend Dobson and Franzmann 1996 emend. Ntougias et al. 2007
}

\author{
Zouhaier Ben Ali Gam, ${ }^{1,2}$ Slim Abdelkafi, ${ }^{1,3}$ Laurence Casalot, ${ }^{1}$ \\ Jean Luc Tholozan, ${ }^{1}$ Ridha Oueslati ${ }^{2}$ and Marc Labat ${ }^{1}$
}

Correspondence

Marc Labat

marc.labat@esil.univmed.fr

\begin{abstract}
${ }^{1}$ Laboratoire de Microbiologie IRD, Biotechnologie Microbienne des Environnements Chauds, UMR D180, IRD ESIL, Universités de Provence et de la Méditerranée, 163 avenue de Luminy, 13288 Marseille cedex 9, France

${ }^{2}$ Laboratoire d'Immuno-Microbiologie Environnementale et Cancérogenèse, Faculté des Sciences de Bizerte, 70021 Zarzouna, Tunisia

${ }^{3}$ Laboratoire des Bio-Procédés, Centre de Biotechnologie de Sfax, Route de Sidi Mansour Km 6, BP 'K', Sfax 3038, Tunisia
\end{abstract}

\begin{abstract}
An aerobic, moderately halophilic, Gram-negative, motile, non-sporulating bacterium, strain LIT2 $^{\top}$, was isolated from an oilfield-water injection after enrichment on crude oil. Strain LIT2 ${ }^{\top}$ grew between 15 and $45{ }^{\circ} \mathrm{C}$ and optimally at $37{ }^{\circ} \mathrm{C}$. It grew in the presence of $1-25 \%(\mathrm{w} / \mathrm{v}) \mathrm{NaCl}$, with an optimum at $10 \%(\mathrm{w} / \mathrm{v}) \mathrm{NaCl}$. Predominant fatty acids were $\mathrm{C}_{16: 0}(26.9 \%), \mathrm{C}_{18: 1} \omega 7 \mathrm{c}$ $(22.6 \%), \mathrm{C}_{16: 1} \omega 7 c(20.4 \%) \mathrm{C}_{19: 0}$ cyclo $\omega 8 c(10.9 \%)$ and $\mathrm{C}_{17: 0}(8 \%)$. Interestingly, the relative percentages of these last two fatty acids were intermediate compared with most species among the family Halomonadaceae for which fatty acid composition has been determined. The DNA G + C content was 53.7 mol\%, which is very low among the family Halomonadaceae. Strain LIT2 ${ }^{\top}$ exhibited $16 \mathrm{~S}$ rRNA gene sequence similarity values of $94.06-95.15 \%$ to members of the genus Chromohalobacter, 94.21-94.65\% to members of the genus Halomonas and $93.57 \%$ with the single species representative of the genus Cobetia. Based on the phylogenetic and phenotypic evidence presented in this paper, we propose the name Modicisalibacter tunisiensis gen. nov., sp. nov. to accommodate strain $\mathrm{LIT}^{\top}{ }^{\top}$. The type strain of Modicisalibacter tunisiensis is LIT2 $^{\top}$ (=CCUG $52917^{\top}=$ CIP $109206^{\top}$ ). A reassignment of the descriptive 16S rRNA signature characteristics of the family Halomonadaceae permitted placement of the new genus Modicisalibacter into the family.
\end{abstract}

The main groups of micro-organisms that are adapted to life in hypersaline environments are distributed across the domains Archaea, Eucarya and Bacteria (Oren, 2002). The halophilic micro-organisms that belong to the Bacteria comprise several representatives that are part of larger phylogenetic groups. The different branches of the phylum Proteobacteria have various halophilic representatives with close relatives that are non-halophilic (Kushner, 1978). Amongst the bacterial families that are part of the class

The GenBank/EMBL/DDBJ accession number for the 16S rRNA gene sequence of strain LIT2 $^{\top}$ is DO641495.
Gammaproteobacteria, the family Halomonadaceae is characterized by halophilic, halotolerant and non-halophilic species that belong to different genera (Franzmann et al., 1988; Prado et al., 2006).

Halomonas, the largest genus in this family, contains 38 species, followed by the genus Chromohalobacter, with seven species. The genus Cobetia was created with the single species Cobetia marina (Arahal et al., 2002). To our knowledge, all the species belonging to these three genera are moderately halophilic, aerobic, Gram-negative, heterotrophic rods. Furthermore, almost all species are motile and capable of reducing nitrate. They have been isolated 
from different terrestrial and aquatic environments, mainly with moderately to high salt concentrations and/or alkaline pH (Ventosa et al., 1989; Arahal et al., 2001a, b; Quillaguamán et al., 2004a).

This report describes the phylogenetic and phenotypic characterization of isolate $\mathrm{LIT}^{\mathrm{T}}$, obtained with two phylogenetically closely related strains (LIT3 and LIT4) from oilfield-water injection samples collected in the south of Tunisia. Based on the physiological and phylogenetic characteristics presented, we propose a new genus and species to accommodate strain LIT2 ${ }^{\mathrm{T}}$.

Samples were collected in sterile glass bottles from different water injections of oilfields located in the Sidi Litayem area near Sfax (Tunisia) and stored in the dark at $4{ }^{\circ} \mathrm{C}$ until use. Enrichments were performed with a basal medium containing $\left(\mathrm{l}^{-1}\right.$ distilled water $) 100 \mathrm{~g} \mathrm{NaCl}, 0.3 \mathrm{~g}$

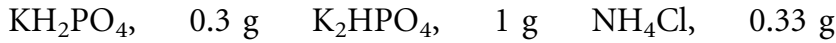
$\mathrm{MgCl}_{2} \cdot 6 \mathrm{H}_{2} \mathrm{O}, 0.1 \mathrm{~g} \mathrm{CaCl} 2,1 \mathrm{~g}$ yeast extract and $1 \mathrm{ml}$ trace-element solution (Widdel \& Pfennig, 1981). The $\mathrm{pH}$ was adjusted to 7.2 with a $10 \mathrm{M} \mathrm{KOH}$ solution. Aliquots of $25 \mathrm{ml}$ were dispensed into flasks and sterilized by autoclaving at $121{ }^{\circ} \mathrm{C}$ for $20 \mathrm{~min}$. Substrates were injected from concentrated sterile stock solutions to obtain the expected final concentration to check the need of the strains for other organic substrates.

Samples $(2.5 \mathrm{ml})$ from oilfield-water injections were used to inoculate $25 \mathrm{ml}$ basal medium supplemented with $1 \%$ crude oil as a carbon source. The cultures were then incubated at $37{ }^{\circ} \mathrm{C}$ under agitation at 150 r.p.m. Each enrichment culture was subcultured several times under the same conditions prior to isolation. For isolation, aliquots $(100 \mu \mathrm{l})$ of $10^{-1}$ to $10^{-10}$ dilutions were plated onto $1 \%$ crude-oil agar basal medium and incubated overnight at $37{ }^{\circ} \mathrm{C}$. Single colonies, originating from different water-injection exhausts and belonging to the same oilfield biotope, were picked and used for screening.

For all experiments, basal medium containing $1 \mathrm{~g}$ yeast extract $\mathrm{l}^{-1}$ was used. The $\mathrm{pH}$ of the medium was adjusted with $5 \mathrm{M} \mathrm{HCl}$ or $10 \mathrm{M} \mathrm{KOH}$ to obtain a range between $\mathrm{pH} 4$ and 11. Different amounts of $\mathrm{NaCl}$ were weighed directly in flasks prior to dispensing $25 \mathrm{ml}$ medium to obtain the expected $\mathrm{NaCl}$ concentration (range $0-250 \mathrm{~g}$ $1^{-1}$ ); the $\mathrm{pH}$ was then readjusted after having added salt in each flask. The temperature range for growth was analysed between 15 and $55^{\circ} \mathrm{C}\left(5{ }^{\circ} \mathrm{C}\right.$ intervals). Nine strains were isolated from the different enrichment cultures initiated with crude oil. All strains were routinely cultured and maintained in the basal medium supplemented with $1 \%$ crude oil, as described below. Three strains, $\mathrm{LIT}_{2}^{\mathrm{T}}$, LIT3 and LIT4, were chosen, and strain LIT2 ${ }^{\mathrm{T}}$ was characterized further. In addition to the isolate, Chromohalobacter canadensis DSM $6769^{\mathrm{T}}$, Chromohalobacter israelensis DSM $6768^{\mathrm{T}}$, Chromohalobacter salexigens DSM $3043^{\mathrm{T}}$, Chromohalobacter marismortui DSM $6770^{\mathrm{T}}$, Chromohalobacter sarecensis CCUG $47987^{\mathrm{T}}$, Chromohalobacter nigrandesensis
DSM $14323^{\mathrm{T}}$, Halomonas ventosae DSM $15911^{\mathrm{T}}$, Halomonas desiderata DSM $9502^{\mathrm{T}}$, Halomonas campisalis ATCC $700597^{\mathrm{T}}$, Halomonas alimentaria DSM $15356^{\mathrm{T}}$ and Cobetia marina DSM $4741^{\mathrm{T}}$ were used as references for phenotypic characteristics. These micro-organisms were cultivated under the same conditions.

Optical and electron microscopy were performed as described by Abdelkafi et al. (2005). For heat resistance, cells grown in basal medium containing yeast extract were exposed to temperatures of 80,90 and $100{ }^{\circ} \mathrm{C}$ for $10 \mathrm{~min}$ (Abdelkafi et al., 2006a). The cells were cooled quickly to room temperature and then inoculated into fresh glucosecontaining medium and growth was recorded after $24 \mathrm{~h}$ of incubation at $37{ }^{\circ} \mathrm{C}$ under agitation (150 r.p.m.).

The Gram reaction was determined by using the bioMérieux Gram stain kit according to the manufacturer's instructions. Catalase activity was determined by bubble production in $3 \%(\mathrm{v} / \mathrm{v})$ hydrogen peroxide solution. Oxidase activity was determined by oxidation of $1 \%$ $p$-aminodimethylaniline oxalate. Other phenotypic characters, including morphological, physiological and biochemical tests, were determined as described previously (Yoon et al., 2001; Romanenko et al., 2003; Quillaguamán et al., 2004a; Abdelkafi et al., 2005). Enzyme activities were examined by using the API ZYM system (bioMérieux). Resistance to antibiotics was determined on MuellerHinton agar (Difco 0252; Becton Dickinson) with standard antibiotic discs (bioMérieux). Inhibition diameters were recorded after $24 \mathrm{~h}$ of incubation at $37{ }^{\circ} \mathrm{C}$ under aerobic conditions. Classification of the strain as sensitive, not sensitive or intermediately sensitive to the antibiotics was proposed according to the disc-manufacturer's instructions (bioMérieux). Fatty acid methyl esters were analysed using the standard procedure of the Microbial Identification System (Microbial ID) and compared to the fatty-acid database. For fatty acid methyl ester analysis, bacteria were grown on blood agar at $30{ }^{\circ} \mathrm{C}$. Bacterial growth was followed by measuring turbidity at $600 \mathrm{~nm}$ by using a Shimadzu model UV 160A spectrophotometer as described by Abdelkafi et al. (2006b).

The $\mathrm{G}+\mathrm{C}$ content of the DNA was determined by the DSMZ (Deutsche Sammlung von Mikroorganismen und Zellkulturen, Braunschweig, Germany) using HPLC as described by Mesbah et al. (1989).

DNA was extracted from nine different isolates, including strain LIT2 ${ }^{\mathrm{T}}$, according to the protocol described for the Wizard Genomic DNA purification kit (Promega). The $16 \mathrm{~S}$ rRNA genes of these isolates were amplified by using primers Fd1 (5'-AGAGTTTGATCCTGGCTCAG-3') and 1525R (5'-AAGGAGGTGATCCAGCC-3') under the following reaction conditions: $1 \mathrm{~min}$ at $96{ }^{\circ} \mathrm{C}, 30$ cycles of $20 \mathrm{~s}$ at $96{ }^{\circ} \mathrm{C}, 30 \mathrm{~s}$ at $55{ }^{\circ} \mathrm{C}$ and $2 \mathrm{~min}$ at $72{ }^{\circ} \mathrm{C}$ and a final elongation step for $5 \mathrm{~min}$ at $72{ }^{\circ} \mathrm{C}$. PCR products were then cloned into the pGEM-T Easy vector (Promega) according to the manufacturer's protocol. Recombinant clones with inserts of the expected length were sequenced 
by using the vector-specific primers SP6 ( $5^{\prime}$-ATTTAGGTGACACTATAGAA- ${ }^{\prime}$ ) and T7 (5'-TAATACGACTCACTATAGGG-3') (Genome Express). Plasmids containing inserts of the expected length were isolated using the Wizard Plus SV Minipreps DNA purification system (Promega) according to the manufacturer's protocol and purified plasmids were sent for sequencing to GATC (Konstanz, Germany). Sequence data were imported into the sequence editor BioEdit version 5.0.9 (Hall, 1999); base calling was examined and a contiguous sequence was obtained. The full sequence was aligned by using the RDP (version 8) Sequence Aligner program (Maidak et al., 2001) and adjusted manually to conform to the 16S rRNA secondary-structure model (Lane et al., 1985). A nonredundant BLAST search (Altschul et al., 1997) identified its closest relatives. Sequences used in the phylogenetic analysis were obtained from the RDP (version 8) (Maidak et al., 2001) and GenBank (Benson et al., 1999) databases. Positions of sequence and alignment ambiguity were omitted and pairwise evolutionary distances were calculated with the method of Jukes \& Cantor (1969). A dendrogram was constructed using the neighbour-joining method (Saitou \& Nei, 1987). Confidence in the tree topology was determined by using 100 bootstrapped trees (Felsenstein, 1985).

The enrichment cultures were positive for crude-oil tolerance after 1 week of incubation at $37^{\circ} \mathrm{C}$ under agitation (150 r.p.m.). After several dilutions and subcultures in the same liquid medium, different stable microbial consortia developed. The morphologically dominant bacterial population was a motile and non-sporeforming bacterium. Subsequently, these enrichment cultures were serially diluted and used to inoculate Petri dishes. Numerous isolates were obtained from these different oilfield-water injection exhausts, and nine different isolates were chosen. The 16S rRNA genes of these nine strains were compared by amplified rDNA restriction analysis (ARDRA) profiles. Three of the pure colonies (LIT2, LIT3 and LIT4) showed similar ARDRA profiles (data not shown). Strain LIT2 $^{\mathrm{T}}$ was selected for further characterization.

\section{Characterization and morphology}

Table 1 provides a comparison of the taxonomic features of strain LIT2 ${ }^{\mathrm{T}}$ with those of some species from the genera Chromohalobacter and Halomonas and the type strain of Cobetia marina. The isolate is a mesophilic, Gram-negative, motile and strictly aerobic bacterium. The catalase reaction is positive. Cells are rod-shaped (1.0-4.0 $\mu \mathrm{m}$ long and 0.6$1.0 \mu \mathrm{m}$ wide). Colonies are smooth, circular, low-convex, cream and $2-3 \mathrm{~mm}$ in diameter after $48 \mathrm{~h}$ at $37^{\circ} \mathrm{C}$. The temperature range supporting growth is $15-45^{\circ} \mathrm{C}$, the optimal temperature being $37{ }^{\circ} \mathrm{C}$. The $\mathrm{pH}$ range for growth is 5-10 with an optimum at $\mathrm{pH}$ 7.2. Moderately halophilic, with a $\mathrm{NaCl}$ range for growth of $10-250 \mathrm{~g} \mathrm{l}^{-1}$ and an optimum at $100 \mathrm{~g} \mathrm{l}^{-1}$. In API ZYM analysis, positive reactions occurred for alkaline phosphatase, esterase, leucine arylamidase, acid phosphatase and esterase lipase.
Negative reactions were observed for naphthol-AS-BIphosphohydrolase, $\alpha$-glucosidase, $\alpha$-fucosidase, cystine arylamidase, lipase, valine arylamidase, trypsin, $\alpha$-chymotrypsin, $\alpha$-galactosidase, $\beta$-glucuronidase, $\beta$-glucosidase, $N$ acetyl- $\beta$-glucosaminidase and $\alpha$-mannosidase. The same biochemical tests were performed with strains LIT3 and LIT4, giving similar results (data not shown). The oxidase reaction distinguished strain $\mathrm{LIT}^{\mathrm{T}}$ clearly from all species of the genus Halomonas (Yoon et al., 2002). Strain LIT2 ${ }^{\mathrm{T}}$ could be differentiated from Cobetia marina by ribose utilization, nitrate reduction, urease activity and by its mobility (Arahal et al., 2002). Strain $\mathrm{LIT}_{2}{ }^{\mathrm{T}}$ could also be distinguished from species of the genus Chromohalobacter by several representative biochemical tests. For example, strain $\operatorname{LIT}_{2}{ }^{\mathrm{T}}$ can be clearly distinguished from its closest phylogenetic relative, Chromohalobacter canadensis DSM $6769^{\mathrm{T}}$ (Arahal et al., 2001a), by its citrate reaction, mannose and ribose utilization and by its aesculin hydrolysis. Similarly, strain $\mathrm{LIT}^{\mathrm{T}}{ }^{\mathrm{T}}$ differs from Chromohalobacter israelensis DSM $6768^{\mathrm{T}}$ (Quillaguamán et al., 2004b) by its utilization of maltose, mannose and aesculin. LIT2 $^{\mathrm{T}}$ can also be distinguished from both Chromohalobacter salexigens DSM $3043^{\mathrm{T}}$ and Chromohalobacter marismortui DSM $6770^{\mathrm{T}}$ by its utilization of mannose, maltose and ribose. Urease activity and $\mathrm{H}_{2} \mathrm{~S}$ production confirmed the differentiation of strain LIT2 from Chromohalobacter salexigens and nitrate reduction and fructose utilization confirmed its differentiation from Chromohalobacter marismortui.

According to this combination of physiological characteristics, strain LIT2 $^{\mathrm{T}}$ can be distinguished by at least three traits from all the species listed in Table 1 belonging to the genera Chromohalobacter, Halomonas and Cobetia. Other useful characteristics to differentiate strain $\mathrm{LIT}^{\mathrm{T}}$ from other phylogenetically related species belonging to the family Halomonadaceae are listed in Table 1.

The growth behaviour of strain LIT2 ${ }^{\mathrm{T}}$ was studied in the presence of different antibiotics. The strain was susceptible to polymyxin $(25 \mu \mathrm{g})$ and colistin $(50 \mu \mathrm{g})$ and was weakly susceptible to penicillin $(10 \mu \mathrm{g})$, but the strain was resistant to tetracycline $(30 \mu \mathrm{g})$, streptomycin $(10 \mu \mathrm{g})$, kanamycin $(30 \mu \mathrm{g})$, neomycin $(30 \mu \mathrm{g})$ and chloramphenicol $(30 \mu \mathrm{g})$.

Strain LIT2 ${ }^{\mathrm{T}}$ has a cellular fatty acid profile containing large amounts of saturated and unsaturated fatty acids (Table 2). The major fatty acids detected in strain $\mathrm{LIT}_{2}{ }^{\mathrm{T}}$ were $\mathrm{C}_{16: 0}$ $(26.9 \%), \mathrm{C}_{18: 1} \omega 7 c(22.6 \%), \mathrm{C}_{16: 1} \omega 7 c$ (20.4\%), $\mathrm{C}_{19: 0}$ $(10.9 \%)$ and $\mathrm{C}_{17: 0}(8 \%)$. This profile is similar in many points to those of the type strains of previously described species belonging to the genera Chromohalobacter, Halomonas and Cobetia, confirming its position in the family Halomonadaceae (Yoon et al., 2002; Peçonek et al., 2006). Moreover, similar to other members of the family Halomonadaceae, strain LIT2 ${ }^{\mathrm{T}}$ possessed low levels of the saturated cellular fatty acids $\mathrm{C}_{10: 0}(2.1 \%), \mathrm{C}_{12: 0}(2.8 \%)$, $\mathrm{C}_{12: 0} 3-\mathrm{OH}(5.6 \%)$ and $\mathrm{C}_{14: 0}(0.7 \%)$. However, important differences were detected in the fatty acid profile of strain $\mathrm{LIT}^{\mathrm{T}}$ when compared with the profiles of representative 
Table 1. Differential characteristics of strain LIT $2^{\top}$ and other strains

Strains: 1, strain $\mathrm{LIT}^{\mathrm{T}}$; 2, Chromohalobacter canadensis DSM $6769^{\mathrm{T}}$ (Arahal et al., 2001b); 3, Chromohalobacter israelensis DSM $6768^{\mathrm{T}}$ (Quillaguamán et al., 2004b); 4, Chromohalobacter salexigens DSM 3043 ${ }^{\mathrm{T}}$ (Vargas et al., 2005); 5, Chromohalobacter marismortui DSM 6770 ${ }^{\mathrm{T}}$ (Ventosa et al., 1989); 6, Halomonas ventosae DSM 15911 ${ }^{\mathrm{T}}$ (Martinez-Canovas et al., 2004); 7, Halomonas desiderata DSM 9502 ${ }^{\mathrm{T}}$ (Yoon et al., 2002); 8, Halomonas campisalis ATCC $700597^{\mathrm{T}}$ (Martinez-Canovas et al., 2004); 9, Halomonas alimentaria DSM 15356 ${ }^{\mathrm{T}}$ (Yoon et al., 2002); 10, Cobetia marina CCUG $49558^{\mathrm{T}}$ (Arahal et al., 2002). +, Positive; -, negative; ND, not determined; NR, not reported.

\begin{tabular}{|c|c|c|c|c|c|c|c|c|c|c|}
\hline Characteristic & 1 & 2 & 3 & 4 & 5 & 6 & 7 & 8 & 9 & 10 \\
\hline Straight rods & + & + & + & + & + & + & + & + & - & + \\
\hline Motility & + & + & + & + & + & + & + & + & - & - \\
\hline Cell size $(\mu \mathrm{m})$ & $\begin{array}{l}1.0-4.0 \\
\times 0.6-1.0\end{array}$ & $\begin{array}{l}2.0-3.8 \\
\times 0.6-1.2\end{array}$ & $\begin{array}{l}1.5-4 \\
\times 0.6-1.0\end{array}$ & $\begin{aligned} & 2-3.0 \\
\times & 0.7-1.0\end{aligned}$ & $\begin{array}{l}1.5-4.0 \\
\times 0.6-1\end{array}$ & $\begin{array}{l}1.2-1.4 \\
\times 0.7-0.8\end{array}$ & $\begin{array}{l}1-2.6 \\
\times 0.4-0.6\end{array}$ & $\begin{array}{r}3-5 \\
\times 1\end{array}$ & $\begin{array}{l}1.3-1.9 \\
\times 0.8-1.2\end{array}$ & $\begin{array}{l}1.6-4 \\
\times 0.8-1.2\end{array}$ \\
\hline Colony form & Convex & Convex & Flat & NR & Convex & Convex & NR & NR & Low-convex & NR \\
\hline Pigmentation & Cream & White & Cream & $\begin{array}{l}\text { White- } \\
\text { cream }\end{array}$ & $\begin{array}{l}\text { Brown- } \\
\text { yellow }\end{array}$ & Cream & Cream & White & $\begin{array}{l}\text { Cream- } \\
\text { yellow }\end{array}$ & NR \\
\hline \multicolumn{11}{|l|}{$\begin{array}{l}\mathrm{NaCl} \text { concentration } \\
\text { for growth }(\%)\end{array}$} \\
\hline Range & $1-25$ & $3-25$ & $3.5-20$ & $0.9-25$ & $2-30$ & $3-15$ & $0-20$ & $1-26$ & $0.5-23$ & $0.5-20$ \\
\hline Optimum & 10 & 8 & 8 & $7.5-10$ & 10 & 8 & $1-5$ & NR & $1-13$ & 5 \\
\hline \multicolumn{11}{|l|}{$\begin{array}{l}\text { Temperature for } \\
\text { growth }\left({ }^{\circ} \mathrm{C}\right)\end{array}$} \\
\hline Range & $4-45$ & $15-45$ & $15-45$ & $4-45$ & $5-45$ & $15-50$ & $10-45$ & $4-50$ & $4-45$ & $10-42$ \\
\hline Optimum & 37 & 30 & 30 & 37 & 37 & $\mathrm{NR}$ & 30 & NR & 30 & 37 \\
\hline \multicolumn{11}{|l|}{$\mathrm{pH}$ for growth } \\
\hline Range & $5-10$ & $5-9$ & $5-9$ & $5-9$ & $5-10$ & $6-10$ & $7-11$ & $6-12$ & $6-12$ & $5-10$ \\
\hline Optimum & $7-7.5$ & NR & NR & 7.5 & 7.5 & NR & NR & NR & $6.5-7.5$ & 7.5 \\
\hline Nitrate reduction & + & + & + & + & - & + & + & + & + & - \\
\hline Indole production & - & - & - & - & - & - & - & NR & - & - \\
\hline Urease activity & - & - & - & + & - & - & + & - & + & + \\
\hline $\mathrm{H}_{2} \mathrm{~S}$ production & - & - & - & + & - & + & + & - & NR & - \\
\hline Oxidase & - & $-^{\star}$ & $-^{*}$ & $-{ }^{*}$ & $-^{*}$ & + & + & + & + & - \\
\hline \multicolumn{11}{|l|}{ Growth on: } \\
\hline Citrate & - & + & ND & + & - & ND & NR & NR & NR & NR \\
\hline Fructose & + & + & ND & + & - & ND & NR & NR & NR & NR \\
\hline Glucose & + & + & ND & + & + & + & + & + & NR & + \\
\hline Mannose & - & + & + & + & + & - & + & - & NR & - \\
\hline Maltose & - & - & + & + & + & + & + & + & NR & - \\
\hline Ribose & - & + & NR & + & + & $\mathrm{ND}$ & - & - & NR & + \\
\hline Xylitol & - & - & NR & NR & NR & ND & NR & NR & NR & NR \\
\hline \multicolumn{11}{|l|}{ Hydrolysis of: } \\
\hline Gelatin & - & - & - & ND & - & - & - & - & - & - \\
\hline Aesculin & - & + & + & ND & - & - & - & - & - & - \\
\hline $\begin{array}{l}\text { DNA G }+ \text { C content } \\
(\mathrm{mol} \%)\end{array}$ & 53.7 & 62 & 65 & $62.4-66$ & $62-65$ & $72.6-74.6$ & 66 & 63 & 66 & 63 \\
\hline
\end{tabular}

${ }^{\star}$ Performed according to Kovacs (1956).

type strains of the genera Chromohalobacter, Halomonas and Cobetia. Indeed, the proportion of $\mathrm{C}_{19: 0}$ cyclo $\omega 8 \mathrm{c}$ found in strain $\operatorname{LIT}_{2}^{\mathrm{T}}(10.9 \%)$ is rather different from that reported for Chromohalobacter sarecensis (28\%) and Cobetia marina $(2.7 \%)$. Quantitative differences for $\mathrm{C}_{17: 0}$ might be used to confirm the differentiation of strains LIT2 ${ }^{\mathrm{T}}$ and LIT3 (ranging from 5.3-8\%) from Halomonas species (ranging from $0.2-1.8 \%$ ). In summary, the fatty acid profiles of strains LIT2 ${ }^{\mathrm{T}}$ and LIT3 differed significantly from those of other members of the family Halomonadaceae (Table 2).
The $\mathrm{G}+\mathrm{C}$ content of genomic DNA of strain $\mathrm{LIT}^{\mathrm{T}}$ was $53.7 \mathrm{~mol} \%$ as determined by HPLC, which is very low amongst the family Halomonadaceae. Nevertheless, this value falls within the range described for species of the family Halomonadaceae (52-74.6 mol\%). Only two species, which are phylogenetically far from strain LIT2 ${ }^{\mathrm{T}}$, show a lower $\mathrm{G}+\mathrm{C}$ content (Halomonas venusta, 52-55 mol\%; Halomonas aquamarina, 57-58 mol\%). The DNA G+C content supported the assignment of strain LIT2 $^{\mathrm{T}}$ to a new genus. 
Table 2. Cellular fatty acid profiles of strains LIT2 ${ }^{\top}$ and LIT3 compared with some species of Chromohalobacter and Halomonas and Cobetia marina

Species/strains: 1, strain $\mathrm{LIT}^{\mathrm{T}}{ }^{\mathrm{T}}$; , strain LIT3; 3, Cobetia marina CCUG $49558^{\mathrm{T}}$; 4, Cobetia marina CCUG 16090; 5, Chromohalobacter sarecensis CCUG $47987^{\mathrm{T}}$; 6, Chromohalobacter beijerinckii CCUG 49679 ${ }^{\mathrm{T}}$; 7, Chromohalobacter marismortui DSM 6770 ${ }^{\mathrm{T}}$ (Peçonek et al., 2006); 8, Halomonas alimentaria (Yoon et al., 2002); 9, Halomonas pacifica (Yoon et al., 2002); 10, Halomonas cupida (Yoon et al., 2002); 11, Halomonas venusta CCUG $16063^{\mathrm{T}}$. Data in columns 3-6 and 11 were obtained from the CCUG; data in columns 7-10 were taken from the publications indicated. Cellular fatty acids were identified with the MIDI system in all cases. Values are percentages of total fatty acids. ND, Not detected.

\begin{tabular}{|lrrrrrrrrrrr|}
\hline Fatty acid & $\mathbf{1}$ & $\mathbf{2}$ & $\mathbf{3}$ & $\mathbf{4}$ & $\mathbf{5}$ & $\mathbf{6}$ & $\mathbf{7}$ & $\mathbf{8}$ & $\mathbf{9}$ & $\mathbf{1 0}$ & $\mathbf{1 1}$ \\
\hline $\mathrm{C}_{10: 0}$ & 2.1 & 2.3 & 1.8 & 2.3 & 1.5 & 0.9 & 2.2 & 2.4 & 2.4 & 3.1 & 2.5 \\
$\mathrm{C}_{12: 0}$ 2. & 2.8 & 2.8 & 3.1 & 3.6 & $\mathrm{ND}$ & 3.2 & 3.6 & $\mathrm{ND}$ & 1.5 & 4.0 & 1.0 \\
$\mathrm{C}_{12: 0}-\mathrm{HH}$ & 5.6 & 6.0 & 6.6 & 4.4 & 7.5 & 6.7 & 8.2 & 7.0 & 5.6 & 8.5 & 6.5 \\
$\mathrm{C}_{14: 0}$ & 0.7 & 0.8 & $\mathrm{ND}$ & $\mathrm{ND}$ & 1.1 & 1.0 & $\mathrm{ND}$ & 0.7 & 0.3 & 0.3 & 2.6 \\
$\mathrm{C}_{16: 0}$ & 26.9 & 27.5 & 29.6 & 29.8 & 31.6 & 36.1 & 18.0 & 18.7 & 25.3 & 22.0 & 10.0 \\
$\mathrm{C}_{17: 0}$ & 8.0 & 5.3 & 13.5 & 10.4 & 20.5 & 23.3 & 3.6 & 0.3 & 0.2 & 0.5 & $\mathrm{ND}$ \\
$\mathrm{C}_{19: 0}$ cyclo $\omega 8 c$ & 10.9 & 7.9 & 2.7 & 1.0 & 28.0 & 24.9 & 25.5 & 7.8 & 18.5 & 15.5 & $\mathrm{ND}$ \\
$\mathrm{C}_{16: 1} \omega 7 c$ & 20.4 & 22.2 & 23.2 & 32.3 & 2.4 & 1.7 & $\mathrm{ND}$ & $\mathrm{ND}$ & $\mathrm{ND}$ & $\mathrm{ND}$ & 15.6 \\
$\mathrm{C}_{18: 1} \omega 7 c$ & 22.6 & 25.3 & 19.5 & 13.3 & 2.0 & 2.2 & 29.8 & 41.4 & 29.8 & 30.7 & 59.0 \\
\hline
\end{tabular}

Almost-complete $16 \mathrm{~S}$ rRNA gene sequences were determined for strains LIT3, LIT4 and LIT2 ${ }^{\mathrm{T}}$. These sequences were aligned and compared with all bacterial sequences available in the GenBank database. A phylogenetic analysis based on 16S rRNA gene sequences showed that strains LIT2 $^{\mathrm{T}}$, LIT3 and LIT4 were members of the family Halomonadaceae. A neighbour-joining tree, showing the phylogenetic relationships between strains LIT2 ${ }^{\mathrm{T}}$, LIT3 and LIT4 and selected representatives of the Halomonadaceae, is presented in Fig. 1. The phylogenetic analyses showed that strains LIT2 ${ }^{\mathrm{T}}$, LIT3 and LIT4 formed a new cluster which was adequate for genus assignment. This new proposed genus is phylogenetically as far from the genus Halomonas as from the genus Chromohalobacter. Thus, strains LIT2 ${ }^{\mathrm{T}}$, LIT3 and LIT4 formed a phylogenetically very cohesive group, where strain LIT2 $^{\mathrm{T}}$ exhibited similarity levels of $95.15-94.06 \%$ with species of the genus Chromohalobacter, 94.65-94.21\% with species of the genus Halomonas and $93.57 \%$ with the type strain of Cobetia marina. Moreover, no other bacterial species shared more than $95.15 \%$ sequence similarity with strain $\mathrm{LIT}^{\mathrm{T}}$. This low level of sequence similarity indicated that strain LIT2 ${ }^{\mathrm{T}}$ could be assigned to a new genus. The sequence of the type strain contained 12 signatures associated with the family Halomonadaceae (data not shown). By extension, it is also proposed that the related strains LIT3 and LIT4 be placed inside the same species of this new genus.

On the basis of these findings, it is proposed that strains LIT2 $^{\mathrm{T}}$, LIT3 and LIT4 represent a novel species in a new genus, Modicisalibacter tunisiensis gen. nov., sp. nov.

\section{Description of Modicisalibacter gen. nov.}

Modicisalibacter (Mo'di.ci.sa'li.bac'ter. L. adj. modicus moderate, limited; L. n. sal, salis salt; N.L. masc. n. bacter a rod; N.L. masc. n. Modicisalibacter a moderately halophilic rod).
Cells are Gram-negative, non-spore-forming, motile rods. Moderately halophilic. Strictly aerobic and require $\mathrm{Na}^{+}$for growth. Mesophilic, growing well at $15-45^{\circ} \mathrm{C}$, oxidasenegative and reduce nitrate. Predominant fatty acids are $\mathrm{C}_{16: 0}, \mathrm{C}_{18: 1} \omega 7 c, \mathrm{C}_{16: 1} \omega 7 c, \mathrm{C}_{19: 0}$ cyclo $\omega 8 c$ and $\mathrm{C}_{17: 0}$. Contents of $\mathrm{C}_{19: 0}$ cyclo $\omega 8 c$ and $\mathrm{C}_{17: 0}$ differ significantly from those of other members of the Halomonadaceae. The DNA $\mathrm{G}+\mathrm{C}$ content of the type strain of the type species is

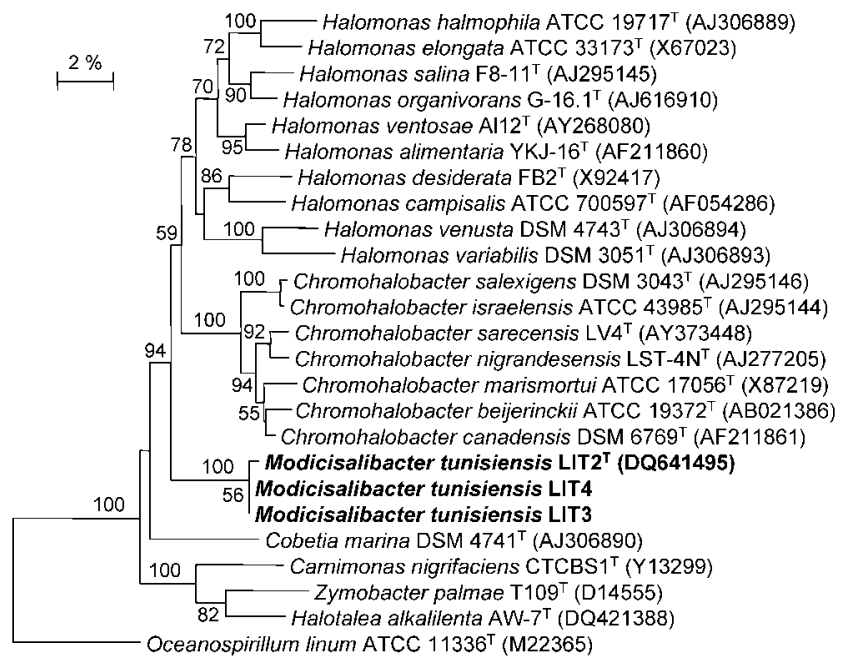

Fig. 1. Phylogenetic dendrogram based on 1322 unambiguous positions of the 16S rRNA gene sequence indicating the positions of strains LIT2 ${ }^{\top}$, LIT3 and LIT4 (Modicisalibacter tunisiensis gen. nov., sp. nov.) and their closest relatives with validly published names belonging to the genera Chromohalobacter and Halomonas and other relatives belonging to the genera Cobetia, Carnimonas, Zymobacter and Halotalea. The tree was constructed using the neighbour-joining algorithm. Accession numbers are included. Bar, 0.02 substitutions per nucleotide position. 
$53.7 \mathrm{~mol} \%$ (HPLC). The genus belongs to the family Halomonadaceae. The type species is Modicisalibacter tunisiensis.

\section{Description of Modicisalibacter tunisiensis sp. nov.}

Modicisalibacter tunisiensis (tu.ni.si.en'sis. N.L. masc. adj. tunisiensis of Tunisia, where the first strains were isolated).

Displays the following properties in addition to those in the genus description. Cells are approximately 1.0-4.0 $\mu \mathrm{m}$ long and $0.6-1.0 \mu \mathrm{m}$ wide. Colonies on marine agar are circular, smooth, convex and $2-3 \mathrm{~mm}$ in diameter after $48 \mathrm{~h}$ of incubation at $37^{\circ} \mathrm{C}$. Cells grow at $4-45^{\circ} \mathrm{C}$, with optimum growth at $37{ }^{\circ} \mathrm{C}$. The $\mathrm{pH}$ range for growth is 510 , with an optimum at $\mathrm{pH}$ 7.2. Optimal growth occurs in the presence of $100 \mathrm{~g} \mathrm{NaCl}^{-1}$. Growth occurs in the range $1-250 \mathrm{~g} \mathrm{NaCl}^{-1}$. Catalase reaction is positive. ONPG hydrolysis is negative. Citrate is not utilized. Urease and arginine dihydrolase are not produced. Gelatin, alginate and aesculin are not hydrolysed. Hydrogen sulfide and indole are not produced. Utilizes D-glucose, D-fructose, tryptone, peptone and Casamino acids. Other characteristics in comparison with closely related species of the genera Chromohalobacter, Halomonas and Cobetia are shown in Table 1. Tests for alkaline phosphatase, esterase, leucine arylamidase, acid phosphatase and esterase lipase are positive. Tests for naphthol-AS-BI-phosphohydrolase, $\alpha$ glucosidase, $\alpha$-fucosidase, cystine arylamidase, lipase, valine arylamidase, trypsin, $\alpha$-chymotrypsin, $\alpha$-galactosidase, $\beta$ glucuronidase, $\beta$-glucosidase, $N$-acetyl- $\beta$-glucosaminidase and $\alpha$-mannosidase are negative. Susceptible to polymyxin $(25 \mu \mathrm{g})$ and colistin $(50 \mu \mathrm{g})$, weakly susceptible to penicillin $(10 \mu \mathrm{g})$ and resistant to tetracycline $(30 \mu \mathrm{g})$, streptomycin $(10 \mu \mathrm{g})$, kanamycin $(30 \mu \mathrm{g})$, neomycin $(30 \mu \mathrm{g})$ and chloramphenicol $(30 \mu \mathrm{g})$. Predominant fatty acids are $\mathrm{C}_{16: 0}$ (26.9\%), $\mathrm{C}_{18: 1} \omega 7 c(22.6 \%), \mathrm{C}_{16: 1} \omega 7 c(20.4 \%), \mathrm{C}_{19: 0}$ cyclo $\omega 8 c(10.9 \%)$ and $\mathrm{C}_{17: 0}(8 \%) . \mathrm{C}_{10: 0}, \mathrm{C}_{12: 0}, \mathrm{C}_{12: 0} 3-\mathrm{OH}$ and $\mathrm{C}_{14: 0}$ are present in smaller amounts.

The type strain is LIT2 ${ }^{\mathrm{T}}\left(=\right.$ CCUG $52917^{\mathrm{T}}=$ CIP $\left.109206^{\mathrm{T}}\right)$, which was isolated from a sample of oilfield-water injection collected in the Sidi Litayem area near Sfax, Tunisia.

\section{Emended description of the family Halomonadaceae Franzmann et al. 1989}

The description of the family Halomonadaceae is as given by Franzmann et al. (1988) and emended previously by Dobson \& Franzmann (1996) and Ntougias et al. (2007), with a single alteration in the 16S rRNA signature nucleotide characteristics. Alignment of sequences was carried out using the CLUSTAL W submission form according to Ntougias et al. (2007). All previous positions of these $16 \mathrm{~S}$ rRNA genes are retrieved with the inclusion of the new genus Modicisalibacter except position 640 (A instead of $\mathrm{G})$. The 16S rRNA signature nucleotides characteristic of the family Halomonadaceae can be redefined as follows: position 484 (A or $\mathrm{G})$, position 486 (C or $\mathrm{U}$ ), position 640 (A or $\mathrm{G})$, position $660(\mathrm{~A})$, position $668(\mathrm{~A})$, position 669 (A), position $737(\mathrm{U})$, position $738(\mathrm{U})$, position $745(\mathrm{U})$, position $776(\mathrm{U})$, position $1124(\mathrm{U}$ or $\mathrm{G})$, position 1297 (U), position $1298(\mathrm{C})$, position $1423(\mathrm{~A})$, position $1424(\mathrm{C}$ or $\mathrm{U}$ ), position 1439 (U or $\mathrm{C}$ ), position 1462 (A or $\mathrm{G}$ ), position 1464 ( $\mathrm{C}$ or $\mathrm{U})$. The family comprises the genera Carnimonas, Chromohalobacter, Cobetia, Halomonas, Halotalea, Modicisalibacter and Zymobacter.

\section{Acknowledgements}

For the realization of this work, Z.B.A.G. received a doctoral fellowship from the Ministry of Research and Technologies (Tunisia) and PACA region (France) within the framework of an international research master BIODEV (Microbial Biotechnology for Sustainable Development), linked with French Universities (Université de Provence, Université de la Méditerranée), French Research Institutes (Institut de Recherches pour le Développement and Institut National des Recherches Agronomiques) and with French UNESCO chairs (UNESCO BIODEV chair). Many thanks are due to S. Ntougias, G. I. Zervakis (both from Institute of Kalamata, Greece) and C. Fasseas (Agricultural University of Athens) for their help in determining the 16S rRNA signature characteristics of the family Halomonadaceae.

\section{References}

Abdelkafi, S., Chamkha, M., Casalot, L., Sayadi, S. \& Labat, M. (2005). Isolation and characterization of a novel Bacillus sp., strain YAS1, capable of transforming tyrosol under hypersaline conditions. FEMS Microbiol Lett 252, 79-84.

Abdelkafi, S., Labat, M., Casalot, L., Chamkha, M. \& Sayadi, S. (2006a). Isolation and characterization of Halomonas sp. strain IMPC, a p-coumaric acid-metabolising bacterium that decarboxylates other cinnamic acids under hypersaline conditions. FEMS Microbiol Lett 255, 108-114.

Abdelkafi, S., Sayadi, S., Ben Ali Gam, Z., Casalot, L. \& Labat, M. (2006b). Bioconversion of ferulic acid to vanillic acid by Halomonas elongata isolated from table-olive fermentation. FEMS Microbiol Lett 262, 115-120.

Altschul, S. F., Madden, T. L., Schäffer, A. A., Zhang, J., Zhang, Z., Miller, W. \& Lipman, D. J. (1997). Gapped BLAST and PSI-BLAST: a new generation of protein database search programs. Nucleic Acids Res 25, 3389-3402.

Arahal, D. R., Garcia, M. T., Ludwig, W., Schleifer, K. H. \& Ventosa, A. (2001a). Transfer of Halomonas canadensis and Halomonas israelensis to the genus Chromohalobacter as Chromohalobacter canadensis comb. nov. and Chromohalobacter israelensis comb. nov. Int J Syst Evol Microbiol 51, 1443-1448.

Arahal, D. R., Garcia, M. T., Vargas, C., Canovas, D., Nieto, J. J. \& Ventosa, A. (2001b). Chromohalobacter salexigens sp. nov., a moderately halophilic species that includes Halomonas elongata DSM 3043 and ATCC 33174. Int J Syst Evol Microbiol 51, 1457-1462.

Arahal, D. R., Castillo, A. M., Ludwig, W., Schleifer, K. H. \& Ventosa, A. (2002). Proposal of Cobetia marina gen. nov., comb. nov., within the family Halomonadaceae to include the species Halomonas marina. Syst Appl Microbiol 25, 207-211.

Benson, D. A., Boguski, M. S., Lipman, D. J., Oullette, B. F. F., Rapp, B. A. \& Wheeler, D. L. (1999). GenBank. Nucleic Acids Res 27, $12-17$. 
Dobson, S. J. \& Franzmann, P. D. (1996). Unification of the genera Deleya (Baumann et al. 1983), Halomonas (Vreeland et al. 1980), and Halovibrio (Fendrich 1988) and the species Paracoccus halodenitrificans (Robinson and Gibbons 1952) into a single genus, Halomonas, and placement of the genus Zymobacter in the family Halomonadaceae. Int J Syst Bacteriol 46, 550-558.

Felsenstein, J. (1985). Confidence limits on phylogenies: an approach using the bootstrap. Evolution 39, 783-791.

Franzmann, P. D., Wehmeyer, U. \& Stackebrandt, E. (1988). Halomonadaceae fam. nov., a new family of the class Proteobacteria to accommodate the genera Halomonas and Deleya. Syst Appl Microbiol 11, 16-19.

Hall, T. A. (1999). BioEdit: a user-friendly biological sequence alignment editor and analysis program for Windows 95/98 NT. Nucleic Acids Symp Ser 41, 95-98.

Jukes, T. H. \& Cantor, C. R. (1969). Evolution of protein molecules. In Mammalian Protein Metabolism, vol. 3, pp. 21-132. Edited by H. N. Munro. New York: Academic Press.

Kovacs, N. (1956). Identification of Pseudomonas pyocyanea by the oxidase reaction. Nature 178, 703.

Kushner, D. J. (1978). Life in high salt and solute concentrations: halophilic bacteria. In Microbial Life in Extreme Environments, pp. 317-368. Edited by D. J. Kushner. London: Academic Press.

Lane, D. J., Pace, B., Olsen, G. J., Stahl, D. A., Sogin, M. L. \& Pace, N. R. (1985). Rapid determination of $16 \mathrm{~S}$ ribosomal RNA sequences for phylogenetic analyses. Proc Natl Acad Sci U S A 82, 6955-6959.

Maidak, B. L., Cole, J. R., Lilburn, T. G., Parker, C. T., Saxman, P. R., Farris, R. J., Garrity, G. M., Olsen, G. J., Schmidt, T. M. \& Tiedje, J. M. (2001). The RDP-II (Ribosomal Database Project). Nucleic Acids Res 29, 173-174.

Martinez-Canovas, M. J., Quesada, E., Llamas, I. \& Bejar, V. (2004). Halomonas ventosae sp. nov., a moderately halophilic, denitrifying, exopolysaccharide-producing bacterium. Int J Syst Evol Microbiol 54, 733-737.

Mesbah, M., Premachandran, U. \& Whitman, W. B. (1989). Precise measurement of the $\mathrm{G}+\mathrm{C}$ content of deoxyribonucleic acid by high-performance liquid chromatography. Int J Syst Bacteriol 39, 159-167.

Ntougias, S., Zervakis, G. I. \& Fasseas, C. (2007). Halotalea alkalilenta gen. nov., sp. nov., a novel osmotolerant and alkalitolerant bacterium from alkaline olive mill wastes, and emended description of the family Halomonadaceae Franzmann et al. 1989, emend. Dobson and Franzmann 1996. Int J Syst Evol Microbiol 57, 1975-1983.

Oren, A. (2002). Diversity of halophilic microorganisms: environments, phylogeny, physiology and applications. J Ind Microbiol Biotechnol 28, 56-63.
Peçonek, J., Gruber, C., Gallego, V., Ventosa, A., Busse, H.-J., Kämpfer, P., Radax, C. \& Stan-Lotter, H. (2006). Reclassification of Pseudomonas beijerinckii Hof 1935 as Chromohalobacter beijerinckii comb. nov., and emended description of the species. Int J Syst Evol Microbiol 56, 1953-1957.

Prado, B., Lizama, C., Aguilera, M., Ramos-Cormenzana, A., Fuentes, S., Campos, V. \& Monteoliva-Sanchez, M. (2006). Chromohalobacter nigrandesensis sp. nov., a moderately halophilic, Gram-negative bacterium isolated from Lake Tebenquiche on the Atacama Saltern, Chile. Int J Syst Evol Microbiol 56, 647-651.

Quillaguamán, J., Hatti-Kaul, R., Mattiasson, B., Alvarez, M. T. \& Delgado, O. (2004a). Halomonas boliviensis sp. nov., an alkalitolerant, moderate halophile isolated from soil around a Bolivian hypersaline lake. Int J Syst Evol Microbiol 54, 721-725.

Quillaguamán, J., Delgado, O., Mattiasson, B. \& Hatti-Kaul, R. (2004b). Chromohalobacter sarecensis sp. nov., a psychrotolerant moderate halophile isolated from the saline Andean region of Bolivia. Int J Syst Evol Microbiol 54, 1921-1926.

Romanenko, L. A., Schumann, P., Zhukova, N. V., Rohde, M., Mikhailov, V. V. \& Stackebrandt, E. (2003). Oceanisphaera litoralis gen. nov., sp. nov., a novel halophilic bacterium from marine bottom sediments. Int J Syst Evol Microbiol 53, 1885-1888.

Saitou, N. \& Nei, M. (1987). The neighbor-joining method: a new method for reconstructing phylogenetic trees. Mol Biol Evol 4, 406-425.

Vargas, C., Kallimanis, A., Koukkou, A. I., Calderon, M. I., Canovas, D., Iglesias-Guerra, F., Drainas, C., Ventosa, A. \& Nieto, J. J. (2005). Contribution of chemical changes in membrane lipids to the osmoadaptation of the halophilic bacterium Chromohalobacter salexigens. Syst Appl Microbiol 28, 571-581.

Ventosa, A., Gutierrez, M. C., Garcia, M. T. \& Ruiz-Berraquero, F. (1989). Classification of "Chromobacterium marismortui" in a new genus, Chromohalobacter gen. nov., as Chromohalobacter marismortui comb. nov., nom. rev. Int J Syst Bacteriol 39, 382-386.

Widdel, F. \& Pfennig, N. (1981). Studies on dissimilatory sulfatereducing bacteria that decompose fatty acids. I. Isolation of new sulfate-reducing bacteria enriched with acetate from saline environments. Description of Desulfobacter postgatei gen. nov., sp. nov. Arch Microbiol 129, 395-400.

Yoon, J.-H., Choi, S. H., Lee, K.-C., Kho, Y. H., Kang, K. H. \& Park, Y.-H. (2001). Halomonas marisflavae sp. nov., a halophilic bacterium isolated from the Yellow Sea in Korea. Int J Syst Evol Microbiol 51, 1171-1177.

Yoon, J.-H., Lee, K.-C., Kho, Y. H., Kang, K. H., Kim, C.-J. \& Park, Y.-H. (2002). Halomonas alimentaria sp. nov., isolated from jeotgal, a traditional Korean fermented seafood. Int J Syst Evol Microbiol 52, 123-130. 